\title{
Hubungan Pengetahuan Ibu Tentang Gizi Balita Dengan Pertumbuhan Berat Badan Balita Pada KMS di Posyandu Dusun Banggel Desa Jebeng Kecamatan Slahung Kabupaten Ponorogo.

\author{
Eliya Rohmah ${ }^{1)}$, Murniati ${ }^{2)}$, Binti Nurdianasari ${ }^{3)}$
}

\begin{abstract}
The growth of toddlers can be known if each month weighed. Weighing results are recorded in KMS, and between the KMS weight point of last month's weighing results and the month's weighing results are attributed to a line. Based on the results of preliminary study on 7 mothers found out the results of two primary school graduates, 2 mothers of junior high school, and 3 mothers of high school graduates. Then the mother was asked about the nutrition of toddlers aged 1-5 years and 4 mothers know but do not understand the whole while 3 mothers do not know at all about nutrition balital-5 years, from 7 mother toddler 3 balitanya experience weight gain while 4 balita weight drop .

This study aims to determine the relationship of mother's knowledge about the nutrition of children under five with weight growth of children under five. The design of this research is analytical method with Cross Sectional approach. With the total population of 61 respondents, the sample of the research is 31 respondents using sampling technique that is accidental sampling. Data collection was obtained by questionnaire and view of KMS. Data were analyzed using spearman rank.

The result of the research shows that from 31 respondents, most of BB did not increase with 19 respondents $(61,3 \%)$ and almost half of them were less knowledge with 14 respondents $(45,2 \%)$. Statistical test using spearman rankdidapatkan $\rho=0.000$ with significance level $\rho<0,05$ then Ho is rejected which means there is relationship of mother knowledge about nutrition of balita with growth of $B B$ and level of closeness strong relation.

Based on the results of the study is expected health workers, especially midwives to improve the role and function of services for the community in providing health information, especially about the importance of weight growth in toddlers.
\end{abstract}

Keywords: knowledge of mother, weight and toddler

\section{PENDAHULUAN}

Sebagian besar anak di dunia sekitar (80\%) yang menderita malnutrisi bermukim diwilayah miskin akan bahan pangan kaya zat besi, terlebih zat gizi makro. Meskipun presentasi malnutrisi terus berkurang tahun demi tahun, angka prevalensi di sebagian wilayah sesungguhnya terus meningkat sebanding dengan laju pertumbuhan. Presentase berat badan di Afrika adanya penyusutan $27 \%$ menjadi $25 \%$ ditahun 2000. Kekurangan elemen kelumit yang meliputi defisiensi vitamin A dan mineral, kalsium, yodium,, besi dan seng, menjangkiti sekitar 2 miliar manusia. Angka kematian bayi (AKB) di
Indonesia diharapkan turun menjadi $20 \%$ menjelang tahun 2020 (Arisman, 2006:v).

Perbaikan gizi masyarakat di Jawa Timur dan di Indonesia pada umumnya masih dihadapkan pada masalah gizi "ganda", yaitu masalah Gizi Kurang dalam bentuk : Kurang Energi Protein (KEP), Gangguan Akibat Kekurangan Yodium (GAKY), Anemia Gizi Besi (AGB) dan Kurang Vitamin A (KVA), serta masalah Gizi Lebih yang erat kaitannya dengan penyakit-penyakit degeneratif. Berbagai upaya perbaikan gizi telah dilakukan di Jawa Timur dalam upaya menanggulangi masalah gizi kurang tersebut, sedangkan untuk masalah 
gizi lebih,masih dilakukan secara individu. Partisipasi masyarakat dalam perbaikan gizi bagi balita dapat ditunjukkan dari indikator jumlah balita yang ditimbang dibagi jumlah sasaran balita (D/S). Tahun 2014, di Jawa Timur angka D/S tercatat sebesar 77,75\% ( Data Profil Kesehatan Tabel47). Pencapaian ini lebih tinggi dibanding dengan pencapaian tahun 2013 sebesar $74,87 \%$. Peningkatan angka D/S ini disebabkan oleh karena adanya peningkatan kinerja petugas kesehatan yang bersinergi dengan stakeholder yang ada di masyarakat,terutama peran Tim Penggerak PKK (Profil kesehatan Jawa Timur 2014,48 ).

Dari Profil Kesehatan Ponorogo Tahun 2014 cakupan anak balita yang mendapatkan pelayanan kesehatan mencapai $78,4 \%$ dari 36.972 anak balita. Terdiri dari $18.705(76,4 \%)$ anak balita laki-laki dan 18.267 (80,3\%) anak balita perempuan. Angka ini menunjukkan penurunan jika dibandingkan dengan cakupan Tahun 2013 cakupan anak balita yang mendapatkan pelayanan kesehatan mencapai $79,08 \%$ dari 38.320 anak balita. Terdiri dari $19.237(76,58 \%)$ anak balita laki-laki dan $19.083(81,76 \%)$ anak balita perempuan. Sedangkan pada tahun 2012 mencapai 78,04 \% dari 49.473 anak balita. Terdiri dari 19.100 $(74,36 \%)$ anak. Balita laki-laki dan $19.508 \quad(82,01 \%)$ anak balita perempuan.

Berdasarkan data yang didapat di Posyandu Dusun Banggel Desa Jebeng Kecamatan Slahung Kabupaten Ponorogo yaitu Menurut SKDN di Dusun Banggel bulan
Oktober 2016 yaitu S: Jumlah balita di Dusun tersebut sebanyak 61 balita, $\mathrm{K}$ : jumlah balita yang terdaftar dan mempunyai KMS 61 balita $(\mathrm{K} / \mathrm{S}, 61 / 61 \times 100 \%=100 \%)$. Dan D : balita yang ditimbang bulan Oktober lalu $56 \quad$ balita (D/S,56/61x100\%=91\%). N : jumlah balita yang naik berat badannya bulan ini $37 \quad$ balita (N/D,37/56x100\%=66\%). Dan $\mathrm{N} / \mathrm{S}, 37 / 61 \times 100 \%=60 \%$, balita yang tidak hadir di posyandu sebanyak 5 anak. Masih terdapat 18 balita yang berat badannya masih turun.

Pentingnya pemantauan pertumbuhan bagi pencegahan menurunnya/memburuknya keadaan gizi anak yang dapat berakibat pada status gizi kurang atau buruk. Selain itu pemantauan pertumbuhan juga penting untuk mempertahankan keadaan gizi baik agar tetap baik. (Depkes RI, 2002: 14).

Posyandu merupakan salah satu bentuk Upaya Kesehatan Bersumber Daya Masyarakat (UKBM) yang dikelola dan diselenggarakan dari, oleh, untuk dan bersama masyarakat dalam penyelenggaraan pembangunan kesehatan guna memberdayaan masyarakat dan memberikan kemudahan dalam masyarakat dalam memperoleh pelayanan kesehatan dasar/sosial dasar keluarga dalam aspek pemantauan tumbuh kembang balita (Kemenkes RI, 2006: 2).

Pertumbuhan balita dapat diketahui apabila setiap bulan ditimbang. Hasil penimbangan dicatat di KMS, dan antara titik berat badan KMS dari hasil penimbangan bulan lalu dan hasil penimbangan bulan ini dihubungkan dengan sebuah garis. Rangakaian garis-garis 
pertumbuhan anak tersebut membentuk grafik pertumbuhan anak. Pada balita yang sehat, berat badannya akan selalu naik, mengikuti pita pertumbuhan sesuai dengan umurnya (Depkes RI, 2006).

Anak yang berumur 1-3 tahun akan mengalami pertambahan berat badan sebanyak 2-2,5 kg, dan tinggi sebesar rata-rata $12 \mathrm{~cm}$ setahun (tahun kedua $12 \mathrm{~cm}$, ketiga $8-9 \mathrm{~cm}$ ). Berat badan baku dapat pula mengacu pada baku berat badan dan tinggi badan dari $\mathrm{WHO} / \mathrm{NCHS}$, atau rumus perkiraan berat badan anak: berat anak usia 1-6 tahun $=\left[\begin{array}{ll}\text { usia } & x \\ 2 & +8\end{array}\right]$. Dengan demikian, berat anak 1 sampai 3 tahun masing-masing 10, 12, dan 14 kg (Arisman, 2005: 55).

Berdasarkan hasil studi pendahuluan yang didapatkan dengan metode wawancara yang peneliti lakukan pada tanggal 16 November 2016 pada 7 ibu balita didapatkan hasil 2 ibu lulusan SD, 2 ibu lulusan SMP, dan 3 ibu lulusan SMA. Kemudian ibu ditanya tentang gizi balita umur 1-5 tahun dan $4 \mathrm{ibu}$ tahu tetapi tidak paham keseluruhan sedangkan 3 ibu tidak tahu sama sekali tentang gizi balita1-5 tahun, dari 7 ibu balita tersebut 3 balitanya mengalami kenaikan berat badan sedangkan 4 balita berat badan turun. Keterangan pada ibu balita tersebut mereka belum pernah mendapat penyuluhan oleh tenaga kesehatan sesudah dilakukan penimbangan di Posyandu.

Gizi adalah makanan yang dapat memenuhi kebutuhan, atau suatu proses organisme menggunakan makanan yang dikonsumsi secara normal melalui transportasi, penyimpangan, metabolisme dan pengeluaran zat-zat yang tidak digunakan untuk mempertahankan kehidupan, pertumbuhan dan fungsi normal dari organ-organ serta menghasilkan energi (Waryana, 2010:6).

Indikator gizi buruk mulai tahun 2013 lebih sensitif daripada tahun-tahun sebelumnya terutama untuk screening anak balita, gizi buruk diverifikasi dengan berat badan dan tinggi badan (Profil kesehatan, 2014:35). Dampak yang terjadi di Posyandu Dusun Banggel Desa Jebeng Kecamatan Slahung Kabupaten Ponorogo dari 18 balita yang mengalami berat badannya turun pada status kesehatannya yang rendah, karena sebagian besar balita di Dusun Banggel Desa Jebeng mengalami sering sakit atau nafsu makan yang sulit. Dampak di tempat penelitian yaitu munculnya kasus pertumbuhan berat badan yang turun dikarenakan kurangnya nafsu makan, balita cenderung menolak makanan yang diberikan.

Keadaan gizi baik, tubuh mempunyai cukup kemampuan untuk mempertahankan diri terhadap penyakit infeksi. Jika keadaan gizi buruk maka reaksi kekebalan tubuh akan menurun yang berarti kemampuan tubuh untuk mempertahankan diri terhadap serangan infeksi menjadi turun ( Notoatmodjo, 2007:248).

Penanggulangan gizi kurang perlu dilakukan secara terpadu antar departemen dan kelompok profesi, melalui upaya-upaya peningkatan pengadaan pangan, penganekaragaman produksi dan konsumsi pangan, peningkatan status sosial ekonomi, pendidikan dan kesehatan masyarakat, serta peningkatan status sosial ekonomi, 


\begin{abstract}
pendidikan dan kesehatan masyarakat serta peningkatan teknologi hasil pertanian dan teknologi pangan. Sedangkan, penanggulangan gizi lebih adalah dengan menyeimbangkan masukan dan keluaran energi melalui pengurangan makan dan penambahan latihan fisik atau olahraga serta menghindari tekanan hidup/stress (Almatsier, 2001:306).

Berdasarkan latar belakang diatas peneliti tertarik untuk mengambil penelitian yang berjudul "Hubungan Pengetahuan Ibu Tentang Gizi Balita Dengan Pertumbuhan Berat Badan Balita pada KMS di Posyandu Dusun Banggel Desa Jebeng Kecamatan Slahung Kabupaten Ponorogo".
\end{abstract}

\section{TINJAUAN PUSTAKA}

\subsection{Konsep dasar pengetahuan}

Pengetahuan merupakan hasil dari "tahu", dan ini terjadi setelah orang melakukan pengindraan terhadap suatu objek tertentu. Pengindraan terjadi melalui pancaindra manusia yakni indra penglihatan, pendengaran, penerimaan rasa, dan raba dengan sendiri. Menurut teori WHO (World Health Organization) yang dikutip oleh Notoatmodjo (2007), salah satu bentuk objek kesehatan dapat dijabarkan oleh pengetahuan yang diperoleh dari pengalaman sendiri.

Faktor-faktor yang Mempengaruhi Pengetahuan:

a. Faktor Internal

1) Pendidikan

2) Umur

b. Faktor Eksternal

1) Faktor Lingkungan

2) Sosial Budaya

\subsection{Konsep Dasar Gizi Balita}

Gizi adalah makanan yang dapat memenuhi kebutuhan, atau suatu proses organisme menggunakan makanan yang dikonsumsi secara normal melalui transportasi, penyimpangan, metabolisme dan pengeluaran zat-zat yang tidak digunakan untuk mempertahankan kehidupan, pertumbuhan dan fungsi normal dari organ-organ serta menghasilkan energi (Waryana, 2010:6).

Gizi balita adalah hal penting utama yang harus diperhatikan oleh orang tua jika ingin tumbuh kembang putra putrinya maksimal.

\section{Status gizi ( Nutrition Status )}

adalah keadaan keseimbangan dalam bentuk variabel tertentu, atau perwujudan dari nutriture dalam bentuk variabel tertentu. Contoh: Gondok endemic merupakan keadaan tidak seimbangnya pemasukan dan pengeluaran yodium dalam tubuh.

Keadaan patologis akibat kekurangan atau kelebihan secara relatif maupun absolut satu atau lebih zat gizi.

Ada empat bentuk malnutrisi:

1) Under Nutrition : Kekurangan atau kelebihan secara relatif atau absolut untuk periode tertentu.

2) Specific Deficiency: Kekurangan zat gizi tertentu, misalnya kekurangan vitamin A, yodium, $\mathrm{Fe}$, dan lain-lain.

3) Over Nutrition: Kelebihan konsumsi pangan untuk periode tertentu.

4) Imbalance: karena disproporsi zat gizi, misalnya: kolestrol terjadi karena tidak seimbangnya LDL ( Low Dencity Lipoprotein), HDL (High Dencity Lipoprotein) dan 
VLDL (Very low Dencity Lipoprotein ) (Supariasa, 2011: 17).

Kebutuhan gizi seseorang adalah jumlah yang diperkirakan cukup untuk memelihara kesehatan pada umumnya. Secara garis besar kebutuhan gizi ditentukan oleh usia, jenis kelamin, aktivitas, berat badan dan tinggi badan. Antara asupan zat gizi dan pengeluarannya harus ada keseimbangan sehingga diperoleh status gizi yang baik. Status gizi balita dapat dipantau dengan menimbang anak setiap bulan dan dicocokkan dengan Kartu Menuju Sehat (KMS).

Konsumsi makanan berpengaruh terhadap status gizi seseorang. Status gizi baik atau status gizi optimal terjadi bila tubuh memperoleh cukup zat-zat gizi yang digunakan secara efisien, sehingga memungkinkan pertumbuhan fisik, perkembangan otak, kemampuan kerja dan kesehatan secara umum pada tingkat setinggi mungkin. Status gizi kurang terjadi bila tubuh mengalami kekurangan satu atau lebih zat-zat gizi esential. Status gizi lebih terjadi bila tubuh memperoleh zat-zat gizi dalam jumlah berlebihan, sehingga menimbulkan efek toksik atau membahayakan. Baik pada status gizi kurang, maupun status gizi lebih terjadi gangguan gizi. Gangguan gizi disebabkan oleh faktor primer atau sekunder (Almaitser, 2003:9).

1) Faktor primer

Adalah bila susunan

makanan seseorang salah dalam kuantitas dan atau kualitas yang disebabkan oleh kurangnya penyediaan pangan, kurang baiknya distribusi pangan, kemiskinan, ketidaktahuan, kebiasaan makan yang salah, dan sebagainya.

2) Faktor sekunder

Meliputi semua faktor yang menyebabkan zat-zat gizi tidak sampai di sel-sel tubuh setelah makanan dikonsumsi. Misalnya faktor-faktor yang menyebabkan terganggunya pencernaan, seperti gigi-geligi yang tidak baik, kelainan struktur saluran cerna dan kekurangan enzim.

3) Faktor-faktor yang mengganggu absorpsi zat-zat gizi adalah:

(a). Parasit

(b). Penggunaan laksan/obat cuci perut.

4) Faktor-faktor yang mempengaruhi metabolisme dan utilisasi zat-zat gizi adalah:

(a). Penyakit Hati.

(b). Diabetes melitus.

(c). Kanker.

(d). Penggunaan obat tertentu.

(e). Minuman Berakohol dan sebagainya.

Akibat kurang gizi terhadap proses tubuh bergantung pada zat-zat gizi apa yang kurang. Kekurangan gizi secara umum (makanan kurang dalam kuantitas dan kualitas) menyebabkan gangguan pada prosesproses:

1) Pertumbuhan

2) Produksi Tenaga

3) Pertahan Tubuh

4) Struktur dan Fungsi Otak

5) Perilaku

Balita termasuk ke dalam kelompok usia berisiko tinggi terhadap penyakit. Kekurangan maupun kelebihan asupan zat gizi pada balita dapat mempengaruhi 
status gizi dan status kesehatan. Gangguan gizi pada balita merupakan dampak kumulatif dari berbagai faktor baik yang terpengruh langsung maupun tidak langsung terhadap gizi anak. Adapun masalah gizi yaitu:

1) Kurang Energi Protein (KEP)

2) Penyakit Kronis

3) Berat Badan kurang

4) Berat badan berlebih

\subsection{Konsep Pertumbuhan}

Pertumbuhan (growth) berkaitan dengan perubahan dalam besar, jumlah, ukuran dan fungsi tingkat sel, organ maupun individu, yang diukur dengan ukuran berat (gram, pound, kilogram), ukuran panjang $(\mathrm{cm}$, meter), umur tulang dan keseimbangan metabolik (retensi kalsium dan nitrogen tubuh). Menurut Jellife D.B. (1989) pertumbuhan adalah peningkatan secara bertahap dari tubuh, organ dan jaringan dari masa konsepsi sampai remaja.

Bukti menunjukkan bahwa kecepatan dari pertumbuhan berbeda setiap tahapan kehidupan karena dipengaruhi oleh kompleksitas dan ukuran dari organ serta rasio otot dengan lemak tubuh. Kecepatan pertumbuhan pada saat pubertas sangat cepat dalam hal tinggi badan yang ditandai dengan perubahan otot, lemak dan perkembangan organ yang diikuti oleh kematangan hormon seks ( Supariasa, 2013:27).

Pertumbuhan anak juga dapat diartikan sebagai perubahan kuantitatif pada material pribadi sebagai akibat adanya pengaruh lingkungan. Material pribadi yang dimaksud adalah sel, kromosom, rambut, butiran darah, dan tulang.
Adapun ciri pertumbuhan anak meliputi pertambahan mateial, baik terkait pertumbuhan yang bersifat kuantitatif maupun kualitatif, asalkan tidak berhubungan dengan fungsinya.

Jika mengacu pada pengertian pertumbuhan anak tersebut, kita dapat menentukan ciriciri yang menunjukkan pertumbuhan anak, yakni bertambahnya berat badan, tinggi badan, lingkaran kepala, tumbuh sekaligus tanggalnya gigi susu dan gigi tetap, serta perubahan tubuh lainnya (Maya,2012:20).

Pertumbuhan adalah pertambahan ukuran-ukuran tubuh yang meliputi BB, LK, lingkar dada, dan lain-lain. Atau bertambahnya jumlah dan ukuran sel-sel pada semua sistem organ tubuh (Lia Dewi, 2010: 48).

Pertumbuhan dipengaruhi oleh dua faktor utama yaitu : faktor internal dan faktor eksternal. Faktor internal seperti biologis, termasuk genetik dan faktor eksternal seperti status gizi.

Pertumbuhan berat badan pada anak umur 0-1 tahun terdapat kenaikan berat badan rata-rata berkisar antara lain :

1) 700- 1000 gram / pada triwulan I

2) 500 - 600 gram / bulan pada triwulan II

3) 350 - 450 gram / bulan pada triwulan II

4) 250 - 350 gram / bulan pada triwulan IV.

\subsection{Konsep dasar berat badan}

Berat badan merupakan ukuran antropometri yang terpenting dan paling sering digunakan pada bayi baru lahir (neonatus ). Berat badan 
digunakan untuk mendiagnosa bayi normal atau BBLR. Dikatakan BBLR apabila berat bayi lahir dibawah 2500 gra atau dibawah 2,5 kg. Pada masa bayi-balita, berat badan dapat dipergunakan untuk melihat laju pertumbuhan fisik maupun status gizi, kecuali terdapat kelainan klinis seperti dehidrasi, asites, edema dan adanya tumor. Disamping itu juga berat badan dapat dipergunakan sebagai dasar perhitungan dosis obat dan makanan. Berat badan menggambarkan jumlah dari protein, lemak, air dan mineral pada tulang ( Supariasa, 2013:39).

Berat badan dipengaruhi oleh:
a. Genetik (keturunan)
b. Asupan nutrisi (makan, minum, dan kudapan)
c. Penyerapan dan pengeluaran usus

d. Aktivitas fisik

e. Metabolisme tubuh dan hormon

f. Kadar air dan lemak tubuh Perubahan dan pertumbuhan serta kecepatan pertumbuhan dapat dilihat pada tabel 1 mengenai umur dan berat badan berikut ini:

Tabel 2.5 Usia dan Berat Badan

\begin{tabular}{|c|c|}
\hline $\begin{array}{c}\text { Golongan umur } \\
(\text { tahun })(\mathrm{kg})\end{array}$ & $\begin{array}{c}\text { Berat badan } \\
(\mathrm{kg})\end{array}$ \\
\hline $0.5 \quad-1$ tahun & 8.0 \\
$1-3$ tahun & 11.5 \\
$4-6$ tahun & 16.5 \\
$7-9$ tahun & 23.5 \\
\hline
\end{tabular}

\subsection{Konsep Dasar Balita}

Balita atau sering disebut bawah lima tahun adalah usia anak yang kurang dari lima tahun, namun karena faal (kerja alat tubuh semestinya). Anak usia 1-5 tahun dapat juga dikatakan mulai disapih atau selepas menyusu atau prasekolah, dengan pertumbuhan dan kecerdasannya dalam memberikan asupan makanan.

Masa balita adalah periode perkembangan fisik dan mental yang pesat. Pada masa ini otak balita telah siap menghadapi berbagai stimulasi seperti belajar berjalan dan berbicara lebih lancar. Berikut ini merupakan prinsip pemberian nutrisi pada balita dan anak pra sekolah:

1. Tinggi energi, protein, vitamin dan mineral

2. Dapat diterima oleh bayi dan anak dengan baik.

3. Diproduksi setempat dan menggunakan bahan-bahan setempat.

4. Mudah didapat dalam bentuk kering dengan demikian mudah disimpan dan praktis penggunaannya.

5. Ringkas tetapi mempunyai nilai gizi maksimum (Marmi, 2013:302).

\subsection{Konsep KMS}

Adalah kartu yang memuat data pertumbuhan serta beberapa informasi lain mengenai perkembangan anak, yang dicatat setiap bulan dari sejak lahir sampai berusia 5 tahun. KMS juga dapat diartikan sebagai "Raport" kesehatan balita. (Departemen kesehatan, 2005: 70).

\subsubsection{Manfaat catatan / informasi pada KMS}

Catatan / informasi pada KMS merupakan alat pemantau keadaan balita yang bisa dijadikan acuan untuk memberikan penyuluhan 
kepada ibu/keluarganya. Selain sebagai acuan penyuluhan, catatan KMS juga dijadikan bahan acuan untuk memberikan rujukan,baik ke langkah -5 maupun ke Puskesmas.

\subsubsection{Cara membaca catatan KMS}

Anak dikatakan berat badannya naik apabila :

1) Garis pertumbuhannya naik mengikuti salah satu pita warna.

2) Garis pertumbuhannya pindah ke Pita warna diatasnya.

Berat badan tidak naik jika :

1) Garis pertumbuhannya menurun.

2) Garis pertumbuhannya mendatar.

3) Garis pertumbuhannya naik tetapi pindah ke pita warna dibawahnya (Departemen kesehatan, 2005: 66).

\section{METODE PENELITIAN}

Jenis penelitian ini adalah koresional yaitu penelitian yang bertujuan untuk menganalisis tentang Hubungan Pengetahuan Ibu tentang gizi balita dengan pertumbuhan berat badan balita pada KMS di Posyandu Dusun Banggel Desa Jebeng Kecamatan Slahung Kabupaten Ponorogo, dengan pendekatan cross sectional. Penelitian ini dilakukan di Posyandu Dusun Banggel Desa Jebeng Kecamatan Slahung Kabupaten Ponorogo, pada bulan Februari 2017.

Dalam penelitian ini yang menjadi populasi adalah ibu balita dan balita yang ada di Posyandu Dusun Banggel Desa Jebeng Kecamatan Slahung Kabupaten Ponorogo. Dengan sampel semua ibu balita dan balita yang ada di Posyandu Dusun Banggel Desa Jebeng Kecamatan Kabupaten Ponorogo. Jumlah sampel dalam penelitian ini adalah 31 orang. Sedangkan teknik Sampling yang digunakan teknik accidental sampling.

Variabel independent dalam penelitian ini adalah "Pengetahuan Ibu tentang gizi balita" dengan variabel Dependent "Pertumbuhan Berat badan". Instrumen yang digunakan adalah lembar observasi dan kuesioner.

Analisa data variabel pengetahuan menggunakan teknik prosentase scoring, sedangkan untuk variabel pertumbuhan berat badan menggunakan observasi langsung menimbang berat badan dan melihat pada KMS (kartu menuju sehat), yang dikategorikan BB naik dan BB tidak naik. Sedangkan untuk mengetahui antara Pengetahuan Ibu tentang gizi dengan Status Gizi Balita digunakan uji korelasi Spearman pada tarif signifikasi 0,05 jika $\mathrm{p}<0,05(5 \%)$ maka Ho ditolak.

4. HASIL PENELITIAN DAN PEMBAHASAN

1) Pengetahuan Ibu Balita Tentang Gizi Balita

Tabel 4.1 Distribusi Pengetahuan Ibu Balita dengan balita Usia 12-60 Bulan Tentang Gizi Balita di Posyandu Dusun Banggel Desa Jebeng Kecamatan Slahung Kabupaten Ponorogo

\begin{tabular}{llcl}
\hline $\mathrm{N}$ & $\begin{array}{l}\text { Distribusi } \\
\text { pengetahu } \\
\text { an }\end{array}$ & $\begin{array}{l}\text { Jumla } \\
\mathrm{h}\end{array}$ & $\begin{array}{l}\text { Presenta } \\
\text { se }\end{array}$ \\
\hline 1 & Baik & 7 & $22,6 \%$ \\
2 & Cukup & 10 & $32,2 \%$ \\
3 & Kurang & 14 & $45,2 \%$ \\
\hline
\end{tabular}


\begin{tabular}{ccc}
\hline Total & 31 & $100 \%$ \\
\hline Sumber : Kuesioner Penelitian 2017
\end{tabular}

Berdasarkan tabel diatas, menunjukkan bahwa dari 31 responden yang diteliti hampir setengahnya berpengetahuan kurang dengan jumlah 14 responden $(45,2 \%)$ dan hampir setengahnya juga 10 responden $(32,2)$ berpengetahuan cukup dan sebagian kecil 7 responden $(22,6 \%)$ berpengetahuan baik.

Sesuai pendapat Wawan (2011:16) semakin bertambah usia, semakin banyak pula pengalaman dan pengetahuan yang dimilikinnya. dimana semakin dewasa seseorang maka pola pikirannya akan semakin berkembang dan kemungkinan penerimaan informasi akan lebih baik. Semakin tinggi latar pendidikan seseorang, maka semakin mudah menerima informasi sehingga makin banyak pula pengetahuan yang dimiliki. Sebaliknya pendidikan rendah akan menghambat pola pengetahuan yang dimiliki seseorang.

Berdasarkan hasil penelitian juga menunjukkan bahwa dari 31 responden hampir setengahnya 18 responden $(58,0 \%)$ berpendidikan SMA, 11 responden $(35,5 \%)$ berpendidikan SMP dan sebagian kecil 2 responden (6,5\%) berpendidikan Sarjana dan tidak satupun responden yang berpendidikan SD.

Berdasarkan data diatas, kurangnya pengetahuan responden disebabkan karena beberapa faktor, khususnya faktor usia dan pendidikan.

\section{2) Pertumbuhan berat badan (BB) pada KMS}

Tabel 4.2 Distribusi pertumbuhan BB Balita pada KMS di Posyandu Dusun Banggel Desa Jebeng Kecamatan Slahung Kabupaten Ponorogo

\begin{tabular}{|c|c|c|c|}
\hline $\begin{array}{l}\mathrm{N} \\
\mathrm{O}\end{array}$ & $\begin{array}{l}\text { Distribusi } \\
\text { Berat badan }\end{array}$ & $\begin{array}{l}\text { Juml } \\
\text { ah }\end{array}$ & $\begin{array}{l}\text { Present } \\
\text { ase }\end{array}$ \\
\hline 1 & Naik & 12 & $38,7 \%$ \\
\hline 2 & Tidak Naik & 19 & $61,3 \%$ \\
\hline & Total & 31 & $100 \%$ \\
\hline
\end{tabular}

Sumber : Kuesioner Penelitian 2017

Berdasarkan tabel diatas, menunjukkan bahwa dari 31 responden yang diteliti sebagian besar BB tidak naik dengan jumlah 19 responden $(61,3 \%)$ dan hampir setengahnya juga 12 responden $(38,7 \%)$ BB naik.

Menurut pendapat lia Dewi (2010), bahwa ada beberapa pengaruh berat badan yaitu (1) genetik (keturunan), (2) Asupan nutrisi (makan,minum, dan kudapan), (3) penyerapan dan pengeluaran usus, (4) aktifitas fisik, (5) metabolisme tubuh dan hormon, (6) kadar lemak dan tubuh dan hormon.

Fakta membuktikan, hampir setengah $(45,2 \%)$ ibu yang pengetahuan kurang tentang Gizi balita dapat mempengaruhi dalam pertumbuhan berat badan balita. Dengan pengetahuan yang baik tentang Gizi balita pertumbuhan berat badan balita usia 12- 60 bulan bisa naik.

Dari pembahasan diatas dapat ditarik opini bahwa sebagian besar dari responden yang memiliki pengetahuan kurang membuat pertumbuhan berat badan balita menjadi turun oleh sebab itu perlu 
dilakukan penyuluhan kepada ibu balita tentang pentingnya Gizi balita.

\section{Uji Statistik}

Tabel 5.8 Hubungan Pengetahuan Ibu Tentang Gizi balita Dengan Pertumbuhan Berat Badan Pada KMS di Posyandu Dusun Banggel, Kec Slahung Kab.Ponorogo

Correlations

\begin{tabular}{|c|c|c|c|}
\hline & & $\begin{array}{c}\text { penget } \\
\text { ahuan }\end{array}$ & BB \\
\hline \multirow{3}{*}{$\begin{array}{l}\text { Spear penget } \\
\text { man's ahuan } \\
\text { rho }\end{array}$} & $\begin{array}{l}\text { Correlation } \\
\text { Coefficient }\end{array}$ & 1.000 & $.713^{* *}$ \\
\hline & $\begin{array}{l}\text { Sig. (2- } \\
\text { tailed) }\end{array}$ & & .000 \\
\hline & $\mathrm{N}$ & 31 & 31 \\
\hline \multirow[t]{3}{*}{ BB } & $\begin{array}{l}\text { Correlation } \\
\text { Coefficient }\end{array}$ & $.713^{* *}$ & 1.000 \\
\hline & $\begin{array}{l}\text { Sig. (2- } \\
\text { tailed) }\end{array}$ & .000 & \\
\hline & $\mathrm{N}$ & 31 & 31 \\
\hline
\end{tabular}

Correlation is significant at the 0.01 level (2-tailed).

Berdasarkan hasil perhitungan menggunakan uji statistik spearman Rank dengan bantuan SPSS 16.0 For Windows pada taraf signifikasi $\rho<0,05$ Ho ditolak dan HI diterima dan diperoleh hasil $\rho=0,000$ yang berarti Ho ditolak sehingga terdapat hubungan pengetahuan ibu tentang gizi balita dengan pertumbuhan berat badan pada KMS di Posyandu Dusun Banggel Desa Jebeng Kecamatan Slahung Kabupaten Ponorogo dengan koefisiensi korelasi 0.713 dengan tingkat hubungan kuat.

Hasil penelitian ini sesuai dengan penelitian Siti Nur Solikah tentang hubungan pengetahuan ibu tentang gizi balita dengan status gizi balita berdasarkan berat badan / umur di Bidan Praktik Mandiri Ernawati, Amd.Keb desa Triagan Kecamatan Kabupaten Sukoharjo Tahun 2012, dengan jenis penelitian ini adalah survey analitik dengan pendekatan cross sectional. Dari hasil penelitian sebagian besar pengetahuan ibu tentang gizi balita adalah cukup sebanyak 8 responden $(40 \%)$, sebagian besar status gizi balita adalah baik sebanyak 8 responden (40\%). Hasil dari penelitian ini berdasarkan nilai koefisien korelasi $\mathrm{P}$ value $<\alpha(0,010$ $<$ 0,05) maka Ho ditolak dan $\mathrm{Ha}$ diterima. Dengan kesimpulan bahwa terdapat hubungan antara hubungan pengetahuan ibu tentang gizi balita dengan status gizi balita berdasarkan berat badan / umur dan kekuatan hubungan adalah kuat.

\section{5) PENUTUP}

\section{Kesimpulan}

$$
\begin{aligned}
& \text { Dari hasil data pada } \\
& \text { penelitian dan pembahasan } \\
& \text { dengan } 31 \text { responden diatas maka } \\
& \text { dapat ditarik kesimpulan antara } \\
& \text { lain sebagai berikut: }
\end{aligned}
$$

1. Pengetahuan ibu tentang Gizi Balita di Posyandu Dusun Banggel Desa Jebeng Kecamatan Slahung Kabupaten Ponorogo didapatkan hasil hampir setengahnya 14 responden (45,2\%) memiliki pengetahuan kurang tentang Gizi Balita.

2. Pertumbuhan berat badan (BB) Balita pada KMS di Posyandu Dusun Banggel Desa Jebeng Kecamatan 
Slahung Kabupaten Ponorogo didapatkan hasil bahwa sebagian besar 19 responden $(61,3 \%)$ berat badannya tidak naik.

3. Ada hubungan antara pengetahuan ibu tentang gizi balita dengan Pertumbuhan berat badan balita pada KMS di Posyandu Dusun Banggel Desa Jebeng Kecamatan Slahung Kabupaten Ponorogo dengan nilai $\rho=0,000$ dan koefisiensi korelasi didapatkan 0,713 yang menunjukkan hubungan kuat.

\section{Saran}

Diharapkan ibu hamil lebih meningkatkan perannya dalam memantau pertumbuhan dan perkembangan balita sesuai usianya. Untuk tenaga kesehatan agar lebih meningkatkan peran dan fungsi pelayanan bagi masyarakat dalam memberikan informasi kesehatan khususnya tentang pentingnya pertumbuhan berat badan pada balita, termasuk memberikan pendidikan kesehatan sedini mungkin bagi ibu balita dan keluarga dengan cara penyuluhan tentang Gizi balita baik secara langsung maupun melalui media masa.

\section{DAFTAR PUSTAKA}

Arikunto. 2010. Prosedur Penelitian Suatu Pendekatan. Edisi revisi. Jakarta : Rineka Cipta.

Effendy, N.1998. Dasar-Dasar Keperawatan Kesehatan Masyarakat. Jakarta : EGC.
Elinofia, dkk. 2011. Hubungan Pendidikan, Pengetahuan, Pekerjaan dan Dukungan Keluarga Dengan Pemberian ASI Eksklusif di Puskesmas Sawah Lebar Kota Bengkulu. (Online),

(http://www.septabakti.ac.id/jo/ index/php/jurnal/118, diakses 29 Desember 2016)

http://depkeg.go.id/downloads/riskes das2013/HasilRiskesdas2013.p df. (Online) (Diakses Pada Hari 26 Tanggal Desember 2016)

Judarwanto. 2006. Penggunaan ASI Eksklusif pada Bayi. (Online), (www.childreclinic.wordpress. com. Diakses 28 Desember 2016)

Khasanah, Nur. 2011. ASI Atau Susu Formula Ya?. Jogjakarta : Flash Books.

Notoatmodjo. 2010. Metodologi Penelitian Kesehatan. Jakarta : Rineka Cipta. . 2003. Pendidikan Dan Perilaku Kesehatan. Jakarta : Rineka Cipta.

Nursalam. 2001. Konsep Dan Penerapan Metodologi Penelitian Ilmu Keperawatan. Jakarta : Salemba Medika. 2003. Konsep Dan Penerapan Metodologi Penelitian Ilmu Keperawatan. Jakarta : Salemba Medika. 2008. Konsep Dan Penerapan Metodologi Penelitian Ilmu Keperawatan. Jakarta : Salemba Medika.

Prasetyono, D. 2012. Buku Pintar ASI Eksklusif. Yogyakarta : Diva Press. 
2009. Buku Pintar ASI Eksklusif. Yogyakarta : Diva Press.

Proverawati, A. 2010. Kapita Selekta ASI dan Menyusui. Yogyakarta : Nuha Medika. 2009. Gizi Untuk Kebidanan. Yogyakarta : Nuha Medika.

Roesli. 2000. Mengenal ASI Eksklusif. Jakarta : Trubus Agriwidya

_ 2005. Petunjuk Praktis Menyusui. Jakarta : Trubus Agriwidya.

Suharso \& Retnoningsih, Ana. 2005. Kamus Besar Bahasa Indonesia. Semarang : Widya Karya

Wawan, A. 2011. Pengetahuan, Sikap dan Perilaku Manusia. Yogyakarta : Nuha Medika 